\title{
Comparison of a Corn Silage Hybrid with High Cell-Wall Content and Digestibility with a Hybrid of Lower Cell-Wall Content on Performance of Holstein Cows*
}

\author{
S. K. Ivan, ${ }^{1}$ R. J. Grant, ${ }^{1}+$ D. Weakley, ${ }^{2}$ and J. Beck ${ }^{3}$ \\ ${ }^{1}$ Department of Animal Science, University of Nebraska, Lincoln 68583-0908 \\ ${ }^{2}$ Purina Mills, St. Louis, MO 63144 \\ ${ }^{3}$ Syngenta Seeds, Golden Valley, MN 55427
}

\begin{abstract}
We hypothesized that substituting a corn hybrid with high cell-wall content and high neutral detergent fiber (NDF) digestibility (HCW) for a hybrid with lower cellwall content and lower NDF digestibility (LCW) would improve feed intake and milk production in lactating Holstein cows. There was a 3.6 percentage unit difference in NDF content and a 4.1 percentage unit difference in 30-h in vitro NDF digestion between the 2 corn hybrids. In trial 1, 40 cows (12 primiparous) ranging in milk production from 24.1 to $44.0 \mathrm{~kg} / \mathrm{d}$, following a 2wk preliminary period, were used in a crossover design with 2 -wk periods. Diets consisted of $45 \%$ corn silage (HCW or LCW), $10 \%$ alfalfa hay, and $45 \%$ concentrates. The DMI (25.4 vs. $24.2 \mathrm{~kg} / \mathrm{d}$ ) and $4 \%$ FCM yield (34.3 vs. $31.7 \mathrm{~kg} / \mathrm{d}$ ) were higher for cows fed the HCW diet compared with the LCW diet. When HCW was substituted for LCW on a DM basis, there was no relationship between pretrial milk yield (preliminary period) and subsequent response to $\mathrm{HCW}$ silage. In trial 2, 40 cows (8 primiparous) ranging in milk production from 20.6 to $49.0 \mathrm{~kg} / \mathrm{d}$, following a 2 -wk preliminary period, were used in a crossover design with 2 -wk periods. Diets consisted of the same LCW diet as trial 1 and a diet containing $\mathrm{HCW}$ at a concentration $(40 \%$ of $\mathrm{DM})$ that resulted in equal NDF content $(30.8 \%)$ between the 2 diets (HCWN). The DMI $(26.8 \mathrm{~kg} / \mathrm{d})$ was unaffected by diet, although there was a trend for greater DMI (\% of BW) for cows fed the HCWN diet compared with LCW silage (4.24 vs. 4.12 ). Milk fat (3.91 vs. $3.79 \%)$ and $4 \%$ FCM yield (34.9 vs. $33.4 \mathrm{~kg} / \mathrm{d}$ ) were greater for cows fed HCWN vs. LCW diet. When HCW was substituted for LCW silage on an NDF basis, cows with greater
\end{abstract}

Received May 19, 2004.

Accepted September 9, 2004.

Corresponding author: R. J. Grant; e-mail: grant@whminer.com.

*Published with the approval of the Director as Paper Number 14578, Journal Series, Nebraska Agricultural Research Division.

$\dagger$ Present address: W. H. Miner Agricultural Research Institute, P.O. Box 90, Chazy, NY 12921. milk production during the preliminary period had a greater milk response to $\mathrm{HCW}$ than lower-producing cows. Results of these trials supported our hypothesis that HCW corn silage results in greater DMI and milk yield than LCW silage, whether substitution occurs on a DM or NDF basis.

(Key words: corn silage, fiber digestibility, milk yield)

Abbreviation key: HCW = high cell-wall content and digestibility corn silage, HCWN = diet that contains the HCW corn silage substituted on an NDF basis, IVNDFD $=$ in vitro NDF digestibility, IVSD $=$ in vitro starch digestibility, $\mathbf{L C W}=$ lower cell-wall content and digestibility corn silage, $\mathbf{M E O}=$ milk net energy output, $\mathbf{P M}=$ pretrial milk yield, $\mathbf{P M E O}=$ pretrial milk net energy output.

\section{INTRODUCTION}

When the land base available for forage production is limited, it becomes increasingly important to develop corn hybrids with greater ruminal DM digestibility, which can provide more energy to the cow. The concern with increasing the digestibility of forages is that many dairy rations are already formulated for minimum dietary NDF and forage NDF content (25 and 19\%, respectively; NRC, 2001), and contain 50\% or greater highly fermentable concentrates. Therefore, increasing the digestibility of the forage fraction could increase the problems observed when feeding higher concentrate diets.

The high NDF content of forages helps to alleviate the problems associated with highly digestible diets by increasing rumination time, which increases saliva production, but NDF can be detrimental to intake and production if fed at high levels. Neutral detergent fiber is correlated negatively with whole-plant in vitro DM digestibility in corn (Cox et al., 1994). Therefore, a highNDF corn silage would be beneficial only if the increased NDF did not limit intake through decreased DM digestibility and ruminoreticular fill. There are also potential economic benefits to feeding a high-NDF corn silage because it would allow for lower concentrations 
of forage in the ration, thereby decreasing the amount of forage that would have to be grown or purchased.

A review by Oba and Allen (1999a) showed that an average 8.4 unit difference in NDF digestion was associated with a mean difference of $2.1 \mathrm{~kg}$ for $4 \% \mathrm{FCM}$ and $1.9 \mathrm{~kg}$ for DMI. Oba and Allen (1999b) suggested that higher producing animals might have a potentially greater response to increased NDF digestibility compared with lower producing animals. Higher producing cows have greater DMI and, therefore, their intake is more likely to be limited by ruminoreticular fill compared with cows that are producing less milk. When feed intake is limited by fill, one approach to increase DMI is to increase NDF digestibility, which increases the rate of NDF clearance from the rumen thereby creating additional space. Because animals at different levels of production may respond differently to increased NDF digestibility (Oba and Allen, 1999b), it is important that any response to a high-NDF digestibility corn silage be related back to initial milk production.

The objectives of this research were: (1) to compare the effect of a high NDF, high NDF digestibility corn hybrid with a lower NDF, lower NDF digestibility corn hybrid on feed intake, milk production and composition, ruminal fermentation, and total tract nutrient digestion, and (2) to relate the response in milk yield to hybrid back to initial milk production.

\section{MATERIALS AND METHODS}

\section{Trial 1 - Forage Substitution on a DM Basis}

Experimental cows and diets. Forty Holstein dairy cows (12 primiparous and 28 multiparous) ranging in milk production from 24.1 to $44.0 \mathrm{~kg} / \mathrm{d}$ (normally distributed with a mean of $32.8 \mathrm{~kg} / \mathrm{d}$ and an SD of $5.1 \mathrm{~kg} /$ d) were assigned to a crossover design after a 2 -wk preliminary period. The DIM ranged from 23 to $243 \mathrm{~d}$ with an average of $113 \mathrm{~d}$. Treatments were not balanced for DIM, but were balanced for primi- and multiparous animals. Experimental periods were $14 \mathrm{~d}$ with the last $7 \mathrm{~d}$ as the collection period. These periods were shorter than common, but previous research (Younker et al., 1998; Voelker et al., 2002) showed that $2 \mathrm{wk}$ is sufficient to evaluate a response to diets with different forage to concentrate ratios and fiber digestibility. Shorter periods were necessary for us to evaluate response to treatment by initial milk production level. Cows were housed in a tie-stall barn and were allowed ad libitum access to diets. The chemical composition and particle-size distribution of the corn silages is shown in Table 1. Both hybrids were grown at the Agriculture Research and Development Center, Mead, NE. They were cut at three-quarters milk-line stage of maturity at a $0.95-\mathrm{cm}$ theoretical length of cut without kernel processing or inoculation and stored in plastic silage bags until initiation of trial 1. The high cell-wall content and digestibility corn silage (HCW) was 3.6 percentage units higher in NDF and 4.1 percentage units higher in $30-\mathrm{h}$ in vitro NDF digestibility (IVNDFD) compared with the lower cell-wall content and digestibility corn silage (LCW). Due to the differing NDF concentrations of the corn silages, the diets were formulated to contain either 29.2 or $31.6 \% \mathrm{NDF}$ for the LCW and the HCW diets, respectively. The diets (Table 2) consisted of $45.1 \%$ of HCW or $45.1 \%$ of LCW. The remainder of both diets consisted of alfalfa hay, ground corn, tallow, SoyPass (Lignotech USA, Rothschild, WI), soybean meal, blood meal, and mineral and vitamin mix.

\section{Trial 2 - Forage Substitution on an NDF Basis}

Forty Holstein dairy cows (8 primiparous and 32 multiparous) ranging in milk production from 20.6 to 49.0 $\mathrm{kg} / \mathrm{d}$ (normally distributed with a mean of $35.14 \mathrm{~kg} / \mathrm{d}$ and a SD of $6.80 \mathrm{~kg} / \mathrm{d}$ ) were assigned to a crossover design after a 2 -wk preliminary period. The average DIM was $140 \mathrm{~d}$ with a range of 19 to $285 \mathrm{~d}$. Treatments were not balanced for DIM, but were balanced for primiand multiparous animals. As in trial 1 , periods were $14 \mathrm{~d}$ in length with the last $7 \mathrm{~d}$ serving as the collection period. Cows were housed in a tie-stall barn and were allowed ad libitum access to diets. The diets (Table 2) consisted of $40.1 \%$ of the HCW silage or $45.1 \%$ of the LCW silage. The LCW diet contained the same ingredients and concentrations as the LCW diet in trial 1. In trial 2, the diet containing the HCW silage (HCWN) was formulated to contain an NDF concentration equal to that in the LCW diet. Ground corn replaced the corn silage in the HCWN diet. The other ingredients in the concentrate mix remained the same as the HCW diet from trial 1.

\section{Trials 1 and 2 - Sampling and Measurements}

For both trials, the experimental periods were $14 \mathrm{~d}$; the last $7 \mathrm{~d}$ were used for sample and data collection. Diets were fed once daily to ensure $10 \%$ orts. Amounts offered and orts were recorded daily to determine DMI. Body weights were measured after the a.m. milking for 3 consecutive days during the last week of each period. Daily milk production was recorded electronically for each cow and a weekly average was calculated. Milk composition samples were collected at 4 consecutive milkings during the last week of each period and analyzed for percentage of milk fat, protein, lactose, and somatic cells (Heart of America DHIA, Manhattan, KS). Eight of the 40 cows were fistulated, and all cows were housed under conditions described in animal use proto- 
IVAN ET AL.

Table 1. Nutrient composition of silages used in trials 1 and 2 (DM basis).

\begin{tabular}{llcc}
\hline & & Silages & \\
\cline { 2 - 4 } Item & LCW & HCW & Preliminary \\
\hline DM, \% as fed & 36.2 & 35.7 & 30.2 \\
CP, \% & 9.6 & 8.8 & 9.5 \\
NDF, \% & $49.2 \pm 1.7$ & $52.8 \pm 0.6$ & 48.0 \\
ADF, \% & 31.3 & 31.8 & 28.3 \\
Lignin, \% & 4.0 & 3.8 & 3.3 \\
Starch, \% & 25.7 & 22.5 & 24.7 \\
IVSD-8 , $^{2} \%$ & 99.1 & 98.8 & $\mathrm{ND}^{4}$ \\
IVNDFD-30 h, \% & $50.7 \pm 2.2$ & $54.8 \pm 3.7$ & ND \\
IVNDFD-48 h, \% & $66.7 \pm 5.2$ & 3.87 \\
Fermentation profile & $58.2 \pm 3.8$ & & 12.2 \\
pH & 3.97 & 3.99 & 8.8 \\
Total acids, \% & 8.8 & 7.6 & 3.1 \\
Lactic acid, \% & 5.5 & 6.0 & 2.8 \\
Acetic acid, \% & 2.9 & 1.1 & 0.2 \\
Lactic/acetic ratio & 2.1 & 6.2 & 0.1 \\
Propionic acid, \% & 0.3 & 0.1 & 8.8 \\
Butyric acid, \% & 0.1 & 0.4 & 6.7 \\
Ammonia N, \% of total N & 9.6 & 9.4 & 75.6 \\
Particle size distribution, ${ }^{5} \%$ of total & & & 16.9 \\
Top (>19 mm) & 4.4 & 3.7 & 47.5 \\
Middle (8 to 19 mm) & 50.3 & 47.7 & \\
Pan (<8 mm) & 44.5 & & \\
\hline
\end{tabular}

${ }^{1} \mathrm{LCW}=$ Low cell wall content and digestibility, $\mathrm{HCW}=$ high cell wall content and digestibility silage, and Preliminary $=$ silage fed during 2 -wk preliminary period.

${ }^{2}$ In vitro rumen starch digestibility measured after $8 \mathrm{~h}$ of incubation.

${ }^{3}$ In vitro rumen NDF digestibility measured after 30 or $48 \mathrm{~h}$ of incubation.

${ }^{4} \mathrm{ND}=$ Not determined.

${ }^{5}$ Measured using the Penn State Particle Size Separator (Lammers et al., 1996).

cols approved by the Institutional Animal Care and Use Committee at the University of Nebraska.

Ingredient and TMR samples were collected and analyzed in a similar manner for trials 1 and 2 . Corn silages, alfalfa hay, concentrate, and TMR samples were collected during the last week of each period for chemical analyses. Samples were oven-dried $\left(60^{\circ} \mathrm{C}\right)$, ground through a Wiley Mill (1-mm screen; Arthur H. Thomas Co., Philadelphia, PA), and analyzed for CP (AOAC, 1990), amylase-modified (heat stable $\alpha$-amylase; ANKOM Tech. Corp., Fairport, NY) NDF (Van Soest et al., 1991), ADF (Van Soest et al., 1991), and acid detergent lignin (Goering and Van Soest, 1970). Sodium sulfite (0.5 g/sample) was added to the concentrate samples to solubilize protein complexes found in the SoyPass ingredient (Hintz et al., 1996). Starch was analyzed according to Fleming and Reichert (1980). Chemical composition of the experimental diets was calculated from the chemical composition of the individual ingredients.

Corn silages were analyzed for 30- and 48-h IVDNFD according to Goering and Van Soest (1970). The 30- or 48-h samples were removed and stored at $-20^{\circ} \mathrm{C}$ and later thawed and analyzed for NDF concentration according to Van Soest et al. (1991). Corn silages were analyzed for in vitro starch digestion (IVSD) according to Richards et al. (1995) and removed after $8 \mathrm{~h}$ of incubation. The Penn State Particle Separator (Lammers et al., 1996) was used to determine particle-size distribution of fresh corn silage and TMR samples (top screen diameter of $19 \mathrm{~mm}$, middle screen diameter of $8 \mathrm{~mm}$ ). Each collection week, a fresh silage sample was used to determine silage $\mathrm{pH}$ and a portion was frozen for determination of the fermentation profile by Dairy One Laboratory (Ithaca, NY).

Ruminal fluid samples were collected from the 8 fistulated cows during the first day of the collection period at $0,4,8,12,16,20$, and $24 \mathrm{~h}$ starting at $0600 \mathrm{~h}$. Digesta samples were collected from beneath the ruminal digesta mat and strained through 4 layers of cheesecloth for immediate $\mathrm{pH}$ determination using a portable $\mathrm{pH}$ meter. Samples $(45 \mathrm{~mL})$ were collected from the strained digesta and stored at $-20^{\circ} \mathrm{C}$ for further analysis. Samples were thawed, treated with $25 \%$ m-phosphoric acid, and centrifuged at $15,000 \times g$ for $15 \mathrm{~min}$ and analyzed for VFA concentration with a gas chromotograph (Hewlett Packard 5890 series II) using run conditions described by Weidner and Grant (1994). The 8 measured values were averaged within cow for each period, and statistics were run on the averaged values.

Fecal samples were collected from the 8 fistulated cows every $9 \mathrm{~h}$ for $3 \mathrm{~d}$ during the collection period and 
Table 2. Ingredient and chemical composition of diets used in trials 1 and 2.

\begin{tabular}{|c|c|c|c|c|}
\hline \multirow[b]{2}{*}{ Item } & \multicolumn{3}{|c|}{$\operatorname{Diets}^{1}$} & \multirow[b]{2}{*}{ Preliminary } \\
\hline & LCW & $\mathrm{HCW}$ & HCWN & \\
\hline \multicolumn{5}{|l|}{ Ingredient, $\%$ of $\mathrm{DM}$} \\
\hline Alfalfa hay & 10.0 & 10.0 & 10.0 & 10.0 \\
\hline Preliminary corn silage & $\ldots$ & $\ldots$ & $\ldots$ & 45.1 \\
\hline LCW corn silage & 45.1 & & $\ldots$ & $\ldots$ \\
\hline HCW corn silage & & 45.1 & 40.1 & \\
\hline Corn, ground & 23.1 & 23.1 & 28.1 & 23.1 \\
\hline Tallow & 1.0 & 1.0 & 1.0 & 1.0 \\
\hline Soypass $^{2}$ & 1.8 & 1.8 & 1.8 & 1.8 \\
\hline Soybean meal & 14.4 & 14.4 & 14.4 & 14.4 \\
\hline Blood meal & 0.9 & 0.9 & 0.9 & 0.9 \\
\hline Mineral and vitamin $\operatorname{mix}^{3}$ & 3.7 & 3.7 & 3.7 & 3.7 \\
\hline \multicolumn{5}{|l|}{ Composition, ${ }^{4} \%$ of DM } \\
\hline $\mathrm{DM}, \%$ & 52.6 & 50.3 & 58 & 49.7 \\
\hline $\mathrm{CP}$ & 18.2 & 17.9 & 18.5 & 18.5 \\
\hline RUP $^{5}$ & 6.3 & 6.3 & 6.4 & 6.3 \\
\hline $\mathrm{ADF}$ & 19.6 & 19.7 & 18.5 & 18.4 \\
\hline $\mathrm{NDF}$ & 30.8 & 33.2 & 30.8 & 31.6 \\
\hline Lignin & 3.0 & 2.7 & 3.0 & 2.5 \\
\hline Starch & 31.1 & 29.7 & 32.1 & 30.7 \\
\hline \multicolumn{5}{|c|}{ Particle size distribution, ${ }^{6} \%$ of total } \\
\hline Top $(>19 \mathrm{~mm})$ & 9.8 & 7.4 & 8.9 & 8.3 \\
\hline Middle ( 8 to $19 \mathrm{~mm}$ ) & 19.3 & 19.5 & 16.7 & 37.0 \\
\hline $\operatorname{Pan}(<8 \mathrm{~mm})$ & 69.8 & 72.3 & 73.6 & 54.0 \\
\hline \multicolumn{5}{|c|}{$\begin{array}{l}{ }^{1} \mathrm{LCW}=\text { Low cell wall content and digestibility, } \mathrm{HCW}=\text { high cell wall content and digestibility substituted } \\
\text { on DM basis, HCWN = high cell wall content and digestibility silage substituted on a NDF basis, and } \\
\text { Preliminary = diet fed during } 2 \text {-wk preliminary period. }\end{array}$} \\
\hline \multicolumn{5}{|c|}{${ }^{2}$ Nonenzymatically browned soybean meal (Lignotech USA, Rothschild, WI). } \\
\hline \multicolumn{5}{|c|}{$\begin{array}{l}{ }^{3} \mathrm{~S} \text { Supplement contained } 21.1 \% \mathrm{Ca}, 2.7 \% \mathrm{P}, 3.1 \% \mathrm{Mg}, 7.7 \% \mathrm{Na}, 1223 \mathrm{ppm} \text { of } \mathrm{Zn}, 854 \mathrm{ppm} \text { of } \mathrm{Mn}, 152 \mathrm{ppm} \\
\mathrm{f} \mathrm{Cu} \text {, and } 60,300,12,030 \text {, and } 417 \mathrm{IU} \text { per kilogram of vitamin } \mathrm{A}, \mathrm{D} \text {, and E, respectively. }\end{array}$} \\
\hline \multicolumn{5}{|c|}{${ }^{4}$ Calculated from chemical composition of individual ingredients. } \\
\hline \multicolumn{5}{|c|}{${ }^{5}$ Calculated using NRC (2001) values for individual ingredients. } \\
\hline${ }^{6}$ Measured using Penn Sta & & & & \\
\hline
\end{tabular}

frozen at $-20^{\circ} \mathrm{C}$. Samples were thawed and composited by cow within period, dried at $60^{\circ} \mathrm{C}$ for $72 \mathrm{~h}$, and ground through a 1-mm Wiley mill screen. Composite samples were then analyzed for OM, NDF, and starch for determination of total tract digestibility. Indigestible NDF (120-h in vitro incubation) was used as the internal marker and total tract digestibility of $\mathrm{OM}, \mathrm{NDF}$, and starch was calculated according to Cochran and Galyean (1994).

Rumen evacuations were performed on the 8 fistulated cows $4 \mathrm{~h}$ before feeding to determine total rumen volume and mass of the rumen contents. A representative sample of rumen contents was taken at that time and frozen at $-20^{\circ} \mathrm{C}$ until further analysis. The ruminal content samples were then thawed and dried at $60^{\circ} \mathrm{C}$ for $72 \mathrm{~h}$ and ground through a 1-mm Wiley mill screen. Samples were analyzed for OM, NDF, and starch, and ruminal pool sizes were calculated by multiplying the digesta DM weight by the concentration of each component. These pool sizes were then used to calculate ruminal turnover rate, which accounts for both digestion and passage, according to Oba and Allen (2000):
Turnover rate in the rumen $(\% / \mathrm{h})=($ intake of component/ruminal pool of component)/24 $\times 100$

\section{Trials 1 and 2 - Statistical Analyses}

All data were analyzed within trial as a crossover design using the MIXED procedure of SAS (SAS Institute, Inc., Cary, NC) according to the following model:

$$
\mathrm{Y}_{\mathrm{ijkl}}=\mu+\mathrm{S}_{\mathrm{i}}+\mathrm{c}_{\mathrm{j}}\left(\mathrm{S}_{\mathrm{i}}\right)+\mathrm{P}_{\mathrm{k}}+\mathrm{T}_{\mathrm{l}}+\mathrm{e}_{\mathrm{ijk} \mathrm{l}}
$$

where $\mu=$ overall mean, $\mathrm{S}_{\mathrm{i}}=$ effect of sequence ( $\mathrm{i}=1$, $2), c_{j}\left(s_{i}\right)=$ random effect of cow nested within sequence $(\mathrm{j}=1,2,3, \ldots 20), \mathrm{P}_{\mathrm{k}}=$ effect of period $(\mathrm{k}=1,2), \mathrm{T}_{1}=$ effect of treatment $(l=1,2)$, and $\mathrm{e}_{\mathrm{ijkl}}=$ residual error, assumed to be normally distributed.

To correlate response to treatment with pretrial milk yield (PM), the response was calculated as follows:

$$
\Delta \mathrm{Y}=\mathrm{y}_{\text {high }}-\mathrm{y}_{\text {low }}
$$

where $\mathrm{y}_{\text {high }}=$ response to the HCW or HCWN diet, and $\mathrm{y}_{\text {low }}=$ response to LCW diet. 
Pretrial milk yield and milk net energy output (PMEO) were calculated as the average milk yield for the last week of the preliminary period. The PMEO was calculated as follows: $\mathrm{NE}_{\mathrm{L}}(\mathrm{Mcal} / \mathrm{d})=\mathrm{MY}(\mathrm{kg}) \times[0.0929$ $\times($ Fat \% $)+0.0563 \times($ True Protein \% $)+0.0395 \times($ Lactose $\%)$ (NRC, 2001). The relationship between response to treatment and PM or PMEO were analyzed according to the following model:

$$
\mathrm{Y}_{\mathrm{i}}=\mu+\mathrm{S}_{\mathrm{i}}+\mathrm{PM}+\mathrm{PM}^{2}+\mathrm{e}_{\mathrm{i}}
$$

where $\mathrm{Y}_{\mathrm{i}}=\mathrm{y}_{\text {high }}-\mathrm{y}_{\text {low }}, \mu=$ overall mean, $\mathrm{S}_{\mathrm{i}}=$ effect of sequence $(\mathrm{i}=1,2), \mathrm{PM}=\mathrm{PM}$ or $\mathrm{PMEO}, \mathrm{PM}^{2}=\mathrm{PM}^{2}$ or $\mathrm{PMEO}^{2}$, and $\mathrm{e}_{\mathrm{i}}=$ residual error, assumed to be normally distributed.

Significance was declared at $P<0.05$ unless otherwise stated, for both trials 1 and 2 .

\section{RESULTS AND DISCUSSION}

\section{Corn Silage and Dietary Nutrient Composition - Trials 1 and 2}

The average nutrient composition of the 2 experimental silages and the preliminary corn silage fed during the 2 trials is shown in Table 1 . The CP content of the HCW silage was slightly lower than the LCW silage. The NDF concentration was 3.6 percentage units higher for the HCW silage compared with the LCW silage; most of that difference appeared to be due to a higher hemicellulose concentration in the HCW silage because the $\mathrm{ADF}$ and lignin concentrations were similar between the 2 treatment silages. The starch concentration was lower in the HCW silage compared with the LCW silage (25.7\% for the LCW silage vs. $22.5 \%$ for the HCW silage). It was expected that the starch concentration would be lower in the HCW silage because NDF concentration is negatively correlated with grain yield (Allen et al., 1991; Cox et al., 1994).

In vitro starch digestibility, after $8 \mathrm{~h}$ of incubation, averaged $99 \%$ and was not different between the 2 experimental silages. The 30 -h IVNDFD was higher for the HCW silage compared with the LCW silage (54.8 vs. $50.7 \%$ for the HCW and LCW silages, respectively). The 48-h IVNDFD was also higher for the HCW silage (66.7\%) compared with the LCW silage (58.2\%). Previous research with the HCW hybrid used in our study (Weiss and Wyatt, 2002), as well as our preliminary work, indicated that the 30-h IVNDFD of the HCW silage would be approximately 4 to 5 percentage units higher compared with a conventional corn silage (we observed 4.1). However, the difference in 48-h IVNDFD values between LCW and HCW silage was almost twice the difference observed by Weiss and Wyatt (2002; 8.5 compared with 4.8 percentage units). All our values for 30-h and 48-h NDF digestion were higher than the values reported by Weiss and Wyatt (2002), with our 30 -h digestibilities being higher than their 48 -h values. The ranges of our IVNDFD compared favorably with values reported previously for corn silage hybrids by Oba and Allen (1999a). Potential reasons for the variability in measured silage NDF digestibility for the same hybrid at 2 different sites are climatic effects due to geography (Ohio vs. Nebraska), year during which the hybrid was grown (Johnson et al., 1999), and donor animal.

The fermentation profiles of the 2 experimental silages were similar (Table 1). The lactic acid concentration was slightly lower and the acetic acid concentration was higher in the HCW silage, which led to a difference in their ratio. Overall, $\mathrm{pH}$ and VFA concentration indicated good silage fermentation. The particle-size distributions of the 2 experimental silages were similar. The corn silage fed during the preliminary period had a nutrient content similar to the LCW silage.

The diets fed during the experimental periods of trials 1 and 2, plus preliminary period diet, contained similar concentrations of DM, CP, RUP, and ADF (Table 2). The particle-size distribution of the 3 experimental diets was similar when measured as fed (Lammers et al., 1996), although the preliminary diet contained more medium-sized particles ( 8 to $19 \mathrm{~mm}$ ) and fewer small particles $(<8 \mathrm{~mm})$. As planned, the HCW diet contained $33.2 \%$ NDF compared with the LCW diet, which contained 30.8\% NDF (Table 2).

\section{Trial 1 - Forage Substitution on a DM Basis}

Milk yield, milk composition, and DMI. The milk yield (35.7 and $33.5 \mathrm{~kg} / \mathrm{d}$ for HCW and LCW, respectively) and $4 \%$ FCM yield ( 34.3 and $31.7 \mathrm{~kg} / \mathrm{d}$ for HCW and LCW, respectively) were significantly higher for cows fed the HCW diet compared with the LCW diet (Table 3). Other recent studies have yielded varying results when a higher NDF digestibility silage replaced a lower digestibility silage (Oba and Allen, 1998; Kuehn et al., 1999). Weiss and Wyatt (2002) observed no difference in milk yield between their control diet and the high-NDF, high NDF digestibility silage (same hybrid as our study) substituted on a DM basis, even though the difference between the $30-\mathrm{h}$ in vitro digestibilities of their silages were similar to what we observed. Valentin et al. (1999) also observed no effect on milk yield of feeding corn silage with increased in situ NDF digestibility compared with a lower digestibility corn silage. However, many studies evaluating brown midrib corn hybrids, which contain less lignin and are considered to have higher in vitro digestibility, have consistently 
Table 3. Milk yield and composition as influenced by experimental diets (trial 1).

\begin{tabular}{|c|c|c|c|c|}
\hline \multirow[b]{2}{*}{ Item } & \multicolumn{2}{|c|}{ Diets $^{1}$} & \multirow[b]{2}{*}{ SEM } & \multirow[b]{2}{*}{$P$} \\
\hline & LCW & HCW & & \\
\hline Milk, kg/d & 33.5 & 35.7 & 0.6 & $<0.01$ \\
\hline $4 \%$ FCM, kg/d & 31.7 & 34.3 & 0.6 & $<0.01$ \\
\hline \multicolumn{5}{|l|}{ Milk fat } \\
\hline$\%$ & 3.68 & 3.75 & 0.08 & 0.38 \\
\hline $\mathrm{kg} / \mathrm{d}$ & 1.22 & 1.33 & 0.03 & $<0.01$ \\
\hline \multicolumn{5}{|l|}{ Milk true protein } \\
\hline$\%$ & 2.91 & 2.93 & 0.03 & 0.54 \\
\hline $\mathrm{kg} / \mathrm{d}$ & 0.97 & 1.04 & 0.02 & $<0.01$ \\
\hline \multicolumn{5}{|l|}{ Milk lactose } \\
\hline$\%$ & 4.89 & 4.85 & 0.04 & 0.24 \\
\hline $\mathrm{kg} / \mathrm{d}$ & 1.64 & 1.73 & 0.04 & 0.03 \\
\hline \multicolumn{5}{|l|}{ Milk SNF } \\
\hline$\%$ & 8.72 & 8.68 & 0.07 & 0.61 \\
\hline $\mathrm{kg} / \mathrm{d}$ & 2.92 & 3.09 & 0.07 & 0.01 \\
\hline $4 \%$ FCM/DMI, kg/kg & 1.32 & 1.36 & 0.04 & 0.24 \\
\hline BW, kg & 617 & 608 & 2 & $<0.01$ \\
\hline
\end{tabular}

${ }^{1} \mathrm{LCW}=$ Low cell wall content and digestibility corn silage, $\mathrm{HCW}=$ high cell wall content and digestibility corn silage substituted on DM basis.

shown an increase in feed intake and milk production for cows fed the brown midrib silage compared with a conventional hybrid (Oba and Allen, 1998; Ballard et al., 2001).

It has been predicted that a 1-unit increase in NDF digestibility, measured in vitro or in situ, would result in a $0.25 \mathrm{~kg} / \mathrm{d}$ increase in $4 \% \mathrm{FCM}$ (Oba and Allen, 1999a). We found that for a 1 percentage unit increase in NDF digestibility, the 4\% FCM yield increased by $0.63 \mathrm{~kg} / \mathrm{d}$ (30-h in vitro NDF digestion) or $0.31 \mathrm{~kg} / \mathrm{d}$ (48$\mathrm{h}$ in vitro NDF digestion). This relationship between increasing NDF digestibility and increasing feed intake and milk yield has been shown to be true in alfalfa silages (Dado and Allen, 1995). We observed no difference in the gross efficiency of converting DMI to $4 \%$ FCM. Due to the increase in milk yield, production of milk fat, milk true protein, lactose, and SNF were all significantly higher for the HCW diet.

The increase in milk yield and 4\% FCM was most likely due to the significant increase in DMI observed for cows fed the HCW diet $(25.4 \mathrm{~kg} / \mathrm{d})$ compared with the LCW diet (24.2 kg/d; Table 4). This difference was also significant when converted to a percentage of BW basis indicating that it was not simply a function of larger cows eating more because they have higher ruminal capacity. Due to the higher NDF content of the HCW diet (33.2\%) compared with the LCW diet (30.8\%), and the increased DMI of cows fed the HCW diet, the NDF intake was also higher for the HCW $\operatorname{diet}(P<0.01)$. Oba and Allen (1999a) determined that a 1-percentage unit increase in NDF digestibility resulted in a 0.17 $\mathrm{kg}$ increase in DMI. We observed that a 1-percentage
Table 4. Feed intake of cows fed diets containing different corn silage hybrids (trial 1).

\begin{tabular}{llllll}
\hline & \multicolumn{3}{c}{ Diets $^{1}$} & & \\
\cline { 2 - 3 } Item & LCW & HCW & & SEM & \multicolumn{1}{c}{$P$} \\
\hline DMI, kg/d & 24.2 & 25.4 & 0.5 & 0.05 \\
DMI, \% of BW & 3.95 & 4.21 & 0.10 & 0.01 \\
NDF intake, kg/d & 7.5 & 8.4 & 0.2 & $<0.01$ \\
NDF intake, \% of BW & 1.21 & 1.39 & 0.03 & $<0.01$ \\
iNDF intake, ${ }^{2} \mathrm{~kg} / \mathrm{d}$ & 2.7 & 2.7 & 0.1 & 0.59 \\
iNDF intake, \% of BW & 0.43 & 0.45 & 0.01 & 0.23 \\
Starch intake, kg/d & 7.5 & 7.5 & 0.2 & 0.43 \\
Starch intake, \% of BW & 1.21 & 1.24 & 0.03 & 0.50 \\
\hline
\end{tabular}

${ }^{1} \mathrm{LCW}=$ Low cell wall content and digestibility corn silage, $\mathrm{HCW}=$ high cell wall content and digestibility corn silage substituted on DM basis.

${ }^{2} \mathrm{iNDF}=$ Indigestible NDF (120-h in vitro incubation).

unit increase in NDF digestion was associated with a $0.29-\mathrm{kg} / \mathrm{d}$ increase in DMI (30-h in vitro NDF digestion) or $0.14 \mathrm{~kg} / \mathrm{d}$ ( 48 -h in vitro NDF digestion). Diet had no influence on consumption of starch or indigestible NDF.

Turnover and total-tract nutrient digestibility. The cows fed the HCW diet were able to produce more milk due to their higher DMI. The increase in DMI was in part possible by the significant increase in $\mathrm{OM}$ and NDF turnover in the rumen observed for the HCW diet compared with the LCW diet (Table 5). It has been thought that increasing the NDF content of the diet, as was the case in the HCW diet, would decrease pas-

Table 5. Ruminal digesta characteristics, total tract digestibility, and ruminal nutrient turnover (trial 1).

\begin{tabular}{lcrrr}
\hline & \multicolumn{2}{c}{ Diets $^{1}$} & & \\
\cline { 2 - 3 } Item & LCW & HCW & SEM & $P$ \\
\hline Ruminal contents & & & & \\
Wet weight, kg & 73.8 & 63.7 & 4.7 & 0.08 \\
Rumen volume, L & 87.1 & 79.5 & 4.2 & 0.11 \\
Dry matter, \% & 15.4 & 14.0 & 0.7 & 0.07 \\
Dry matter, kg & 11.3 & 8.9 & 0.7 & 0.01 \\
NDF, \% of DM & 65.6 & 65.6 & 1.9 & 0.99 \\
NDF, kg & 7.3 & 5.8 & 0.3 & $<0.01$ \\
Total tract digestibility, \% & & & & \\
OM & 62.1 & 61.2 & 1.3 & 0.53 \\
NDF & 39.1 & 43.3 & 1.2 & 0.01 \\
Starch & 89.2 & 85.7 & 2.5 & 0.22 \\
Ruminal turnover, \%/h & & & & \\
$\mathrm{K}_{\mathrm{OM}}$ & 10.84 & 12.64 & 0.78 & 0.06 \\
$\mathrm{~K}_{\mathrm{NDF}}$ & 5.07 & 6.30 & 0.25 & $<0.01$ \\
$\mathrm{~K}_{\text {starch }}$ & 92.24 & 103.05 & 18.36 & 0.60 \\
$\mathrm{~K}_{\mathrm{p}}^{2}$ & 3.11 & 3.60 & 0.23 & 0.08 \\
\hline
\end{tabular}

${ }^{1} \mathrm{LCW}=$ Low cell wall content and digestibility corn silage, $\mathrm{HCW}=$ high cell wall content and digestibility corn silage substituted on DM basis.

${ }^{2}$ Passage rate as measured by indigestible NDF of TMR and ruminal digesta. 
sage rate of the diet, but in this situation, it appears that the higher rate of NDF digestion in the rumen was able to overcome the presumed decrease in passage rate due to higher NDF concentration (Shaver et al., 1988). The wet digesta weight $(P<0.09)$, ruminal volume $(P$ $<0.12)$, and digesta DM weight $(P<0.12)$ all tended to be lower for the HCW diet compared with the LCW diet, indicating that higher NDF digestibility of the HCW diet was decreasing ruminal fill. Starch turnover in the rumen was not significantly different between the treatments. The passage rate of the indigestible NDF fraction was not affected by diet indicating that the high turnover of $\mathrm{OM}$ and NDF observed for the HCW diet was influenced more by increased ruminal digestion than by increased passage rate.

The majority of dietary NDF is degraded in the rumen, and the higher ruminal turnover of NDF in the rumen is reflected in the significantly higher total-tract NDF digestibility observed for cows fed the HCW diet (43.3\%) compared with the LCW diet (39.1\%). In contrast, total-tract $\mathrm{OM}$ and starch digestibilities were not different between the diets. Oba and Allen (1999b) observed no difference in total-tract OM digestibility between a brown midrib corn hybrid and a conventional corn hybrid, even though the brown midrib silage had a higher apparent and true ruminal OM digestibility. However, in their study, the passage rate for the brown midrib diet was also faster so that the increased rate of passage could have negated any increase in rumen digestibility. Other studies have also shown no difference in total-tract OM digestibility of a high-NDF digestibility and a lower NDF digestibility silage (Kuehn et al., 1999; Oba and Allen, 1999b; Bal et al., 2000). One possible explanation for the increase in ruminal turnover without an increase in total-tract OM digestibility is that the increased digestibility of the NDF in the rumen accounted for much of the increase in OM turnover in the rumen, but postruminally the OM that was passed out of the rumen was digested similarly between the 2 diets.

Ruminal pH and VFA concentrations. The ruminal $\mathrm{pH}$ was not different between the HCW and the LCW diets (5.97 and 5.94, respectively). Ruminal concentrations of acetate, butyrate, and total VFA were not affected by diet (Table 6). Similarly, Weiss and Wyatt (2002) showed no effect of feeding the same high-NDF, high-NDF digestibility silage compared with a conventional silage on total VFA concentrations. The LCW diet resulted in greater propionate concentration, and lower acetate to propionate ratio, presumably due to the lower NDF and slightly greater starch content of the LCW diet compared with the HCW diet.

Relationship of milk response to pretrial milk yield. It appears that the increased NDF digestibility
Table 6. Ruminal $\mathrm{pH}$ and VFA concentrations as influenced by diet (trial 1).

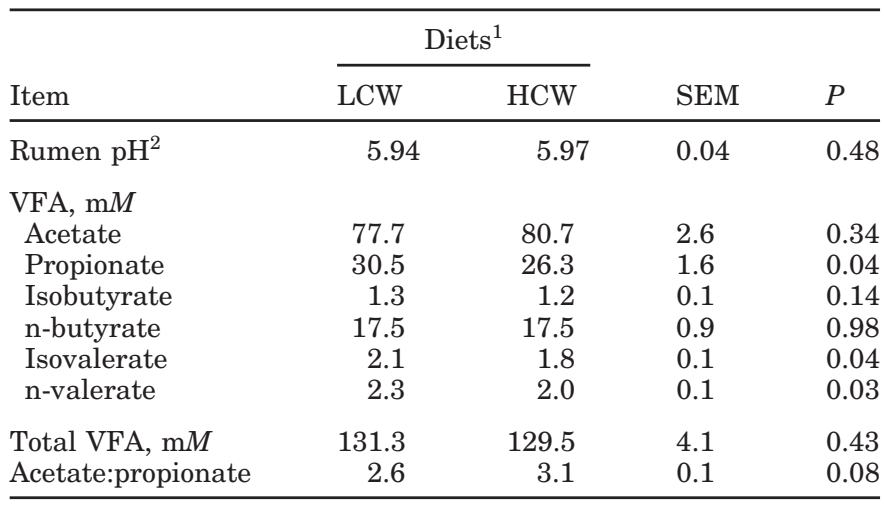

${ }^{1} \mathrm{LCW}=$ Low cell wall content and digestibility, $\mathrm{HCW}=$ high cell wall content and digestibility substituted on DM basis.

${ }^{2} \mathrm{Mean} \mathrm{pH}$ and VFA from samples collected every $4 \mathrm{~h}$ for $24 \mathrm{~h}$.

of the corn silage allowed for an increased DMI mostly due to the increase in NDF and OM turnover in the rumen. When the response to the HCW diet was compared with PM, there was no effect of initial milk yield on subsequent response to diet (Figure 1; linear: $P>$ 0.18 ; quadratic: $P>0.45$ ). For energy-corrected milk, there was a significant quadratic response to the HCW diet with higher and lower pretrial milk energy output equating to a greater response to the HCW diet. However, the overall shape of the curve implies that there is little biological significance to this relationship. Other factors such as DIM, parity, and BW could influence $\mathrm{PM}$ and therefore the response to the treatment. There was a negative correlation between pretrial DIM and $\mathrm{PM}\left(\mathrm{r}^{2}=(0.39)\right.$, which reflects our use of late-lactation animals to create the lower end of our range in pretrial milk production. The relationship observed in our study disagrees with results from previous studies that have shown an increased FCM response to lower forage diets (Voelker et al., 2002) and brown midrib silage-containing diets (Oba and Allen, 1998) for cows that were at higher levels of milk production before the initiation of the study

\section{Trial 2 - Forage Substitution on an NDF Basis}

Milk yield, milk composition, and DMI. There was no effect of treatment on milk yield, but $4 \%$ FCM was significantly higher for cows fed the HCWN diet (Table 7). In this trial, substituting the HCW silage, on a NDF basis, for the LCW silage resulted in lower inclusion of the HCW silage. Therefore, the benefit of the increased NDF digestibility of this silage may not be as pronounced due to its lower concentration in the diet. However, for 30-h IVNDFD we observed a 0.30 $\mathrm{kg}$ increase in $4 \% \mathrm{FCM}$ production for a 1 percentage 
A

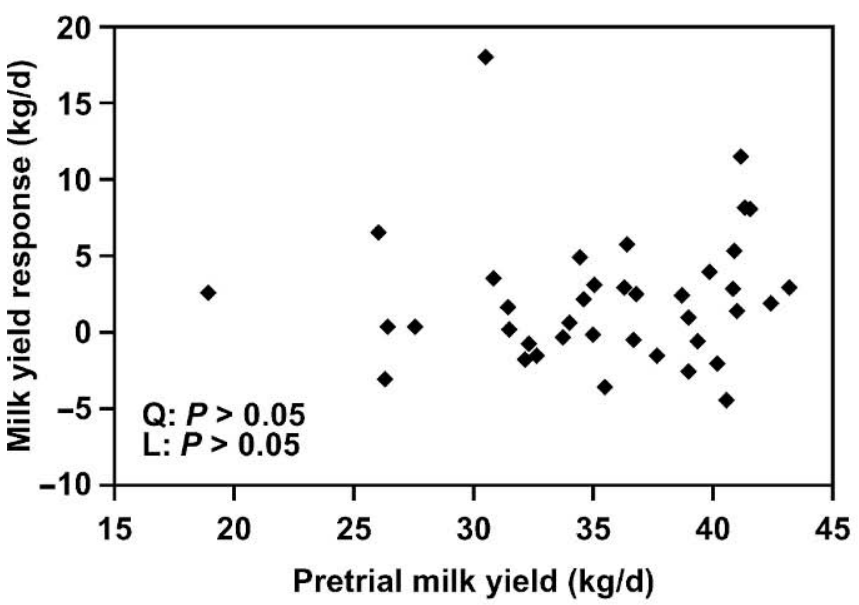

B

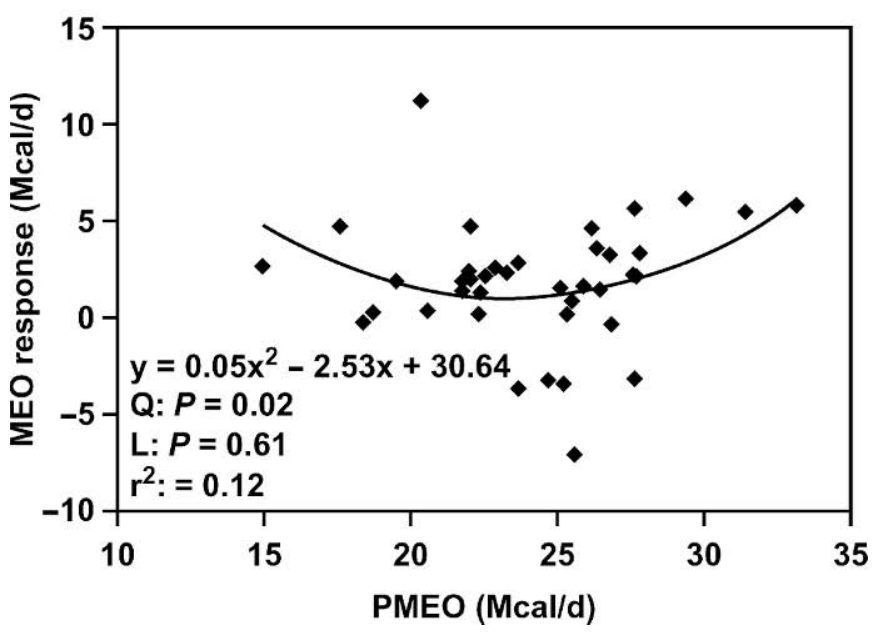

Figure 1. Relationship between pretrial milk yield or milk energy output, measured during the last week of a 2-wk preliminary period, and response to HCW (high cell-wall content and digestibility corn silage substituted on a DM basis) diet versus the LCW (low cell-wall content and digestibility) diet for: A) milk yield, or B) milk net energy output $\left(\mathrm{SE}\right.$ for $\mathrm{x}^{2}=0.02, \mathrm{x}=1.17$, and intercept $\left.=14.12\right)$. Milk net energy output was calculated as follows: $\mathrm{NE}_{\mathrm{L}(\mathrm{milk})}(\mathrm{Mcal} / \mathrm{d})=\mathrm{MY}(\mathrm{kg})$ $\times[0.0929 \times($ Fat \% $)+0.0563 \times($ True Protein \% $)+0.0395 \times$ (Lactose $\%)$ (NRC, 2001). PMEO = Pretrial milk net energy output, $\mathrm{MEO}=$ milk net energy output, $\mathrm{Q}=$ quadratic, $\mathrm{L}=$ linear.

unit increase in NDF digestibility, which is consistent with previous observations (Oba and Allen, 1999a). Using the 48-h IVNDFD value resulted in a smaller increase in $4 \% \mathrm{FCM}$ per 1 percentage unit increase in digestibility $(0.17 \mathrm{~kg})$.

Interestingly, there was a tendency $(P<0.07)$ for an increase in milk fat concentration for the HCWN diet compared with the LCW diet. Weiss and Wyatt (2002) observed a significant milk fat depression when the high-NDF, high-NDF digestibility corn silage was substituted for low cell-wall corn silage on a NDF basis.
Table 7. Milk yield and composition as influenced by experimental diets (trial 2).

\begin{tabular}{lrrrrr}
\hline & \multicolumn{3}{c}{ Diets $^{1}$} & & \\
\cline { 2 - 3 } Item & LCW & HCWN & SEM & $P$ \\
\hline Milk, kg/d & 34.6 & 35.5 & 0.5 & 0.14 \\
4\% FCM, kg/d & 33.4 & 34.9 & 0.6 & 0.03 \\
Milk fat & 3.79 & 3.91 & 0.06 & 0.07 \\
\% & 1.30 & 1.38 & 0.03 & 0.03 \\
kg/d & & & & \\
Milk true protein & 3.07 & 3.12 & 0.03 & 0.13 \\
kg/d & 1.05 & 1.10 & 0.02 & 0.07 \\
Milk lactose & & & & \\
\% & 4.79 & 4.83 & 0.04 & 0.36 \\
kg/d & 1.66 & 1.72 & 0.03 & 0.10 \\
Milk SNF & & & & \\
\% & 8.79 & 8.88 & 0.07 & 0.23 \\
kg/d & 3.03 & 3.15 & 0.06 & 0.09 \\
4\% FCM/DMI, kg/kg & 1.28 & 1.31 & 0.03 & 0.39 \\
BW, kg & 647 & 641 & 2 & $<0.01$ \\
\hline
\end{tabular}

${ }^{1} \mathrm{LCW}=$ Diet containing the low cell wall content and digestibility corn silage, HCWN = diet containing the high cell wall content and digestibility substituted on an NDF basis.

Weiss and Wyatt (2002) could not determine whether the decrease in milk fat percentage for cows fed the high cell-wall diet was due to increased corn grain and therefore starch concentration of the diet, increased NDF digestibility of the corn silage, decreased NDF concentration, or a combination of these 3 factors. In our study, we were able to reduce the overall forage concentration of the diet while maintaining equal NDF concentration of the diets, which not only prevented a depression in milk-fat concentration, but also actually increased milk-fat concentration in the HCWN diet. There was a trend $(P=0.13)$ for an increase in milk true protein concentration for cows fed the HCWN diet. The increased energy available to the rumen may have increased microbial protein synthesis and consequently metabolizable protein supply to the cow (Oba and Allen, 2000). The concentration of lactose and SNF were not affected by treatment, but due to the trend for an increase in milk yield, the production of all milk components was increased for cows fed HCWN compared with the LCW diet. As observed in trial 1, there was no effect of treatment on gross efficiency of converting DMI to $4 \%$ FCM.

The DMI response paralleled the milk yield response (Table 8$)$. There was a trend $(P=0.13)$ for an increase in DMI for cows fed the HCWN diet compared with the LCW diet as a percentage of BW. Weiss and Wyatt (2002) observed no effect on DMI of substituting a higher NDF content and digestibility silage for a lower NDF corn silage, on a NDF basis. There was no difference in NDF or starch intake between the diets, which, given similar DMI for the 2 diets, was expected because 
Table 8. Feed intake of cows fed diets containing different corn silage hybrids (trial 2).

\begin{tabular}{|c|c|c|c|c|}
\hline \multirow[b]{2}{*}{ Item } & \multicolumn{2}{|c|}{$\operatorname{Diets}^{1}$} & \multirow[b]{2}{*}{ SEM } & \multirow[b]{2}{*}{$P$} \\
\hline & LCW & HCWN & & \\
\hline DMI, kg/d & 26.5 & 27.1 & 0.5 & 0.32 \\
\hline DMI, \% of BW & 4.12 & 4.21 & 0.08 & 0.13 \\
\hline NDF intake, $\mathrm{kg} / \mathrm{d}$ & 8.2 & 8.3 & 0.2 & 0.31 \\
\hline NDF intake, $\%$ of $\mathrm{BW}$ & 1.26 & 1.32 & 0.04 & 0.12 \\
\hline iNDF intake, ${ }^{2} \mathrm{~kg} / \mathrm{d}$ & 2.9 & 2.4 & 0.1 & $<0.01$ \\
\hline iNDF intake, $\%$ of BW & 0.45 & 0.38 & 0.01 & $<0.01$ \\
\hline Starch intake, kg/d & 7.7 & 7.9 & 0.2 & 0.25 \\
\hline Starch intake, $\%$ of BW & 1.19 & 1.25 & 0.04 & 0.12 \\
\hline
\end{tabular}

${ }^{1} \mathrm{LCW}=$ Low cell wall content and digestibility corn silage, $\mathrm{HCWN}=$ high cell wall content and digestibility corn silage substituted on a NDF basis.

${ }^{2} \mathrm{iNDF}=$ Indigestible NDF (120-h in vitro incubation).

the NDF concentration of the LCW and HCWN diets was $30.8 \%$, and both diets had similar starch concentrations.

Ruminal turnover and total-tract nutrient digestibility. There was no difference in ruminal turnover of OM or starch, but there was a trend for an increase in NDF turnover for the HCWN $\operatorname{diet}(P=0.12$; Table 9). There was no difference in ruminal passage of indigestible NDF between the cows fed the LCW diet and cows fed the HCWN diet. Total tract digestibilities of $\mathrm{OM}$ and starch were also very similar between the 2 treatments, but NDF digestibility for cows fed the

Table 9. Ruminal digesta characteristics, total tract digestibility, and ruminal nutrient turnover (trial 2).

\begin{tabular}{|c|c|c|c|c|}
\hline \multirow[b]{2}{*}{ Item } & \multicolumn{2}{|c|}{$\operatorname{Diets}^{1}$} & \multirow[b]{2}{*}{ SEM } & \multirow[b]{2}{*}{$P$} \\
\hline & LCW & HCWN & & \\
\hline \multicolumn{5}{|l|}{ Ruminal contents } \\
\hline Wet weight, kg & 72.2 & 65.4 & 4.6 & 0.19 \\
\hline Rumen volume, $\mathrm{L}$ & 92.0 & 85.6 & 6.1 & 0.35 \\
\hline Dry matter, \% & 16.6 & 17.6 & 1.0 & 0.35 \\
\hline Dry matter, kg & 12.0 & 11.4 & 1.0 & 0.54 \\
\hline $\mathrm{NDF}, \%$ of DM & 63.3 & 60.7 & 1.8 & 0.20 \\
\hline $\mathrm{NDF}, \mathrm{kg}$ & 7.6 & 7.0 & 0.7 & 0.41 \\
\hline \multicolumn{5}{|c|}{ Total tract digestibility, $\%$} \\
\hline $\mathrm{OM}$ & 61.9 & 62.9 & 2.1 & 0.64 \\
\hline $\mathrm{NDF}$ & 36.5 & 46.9 & 1.9 & $<0.01$ \\
\hline Starch & 83.5 & 79.7 & 3.1 & 0.27 \\
\hline \multicolumn{5}{|c|}{ Ruminal turnover, $\% / \mathrm{h}$} \\
\hline $\mathrm{K}_{\mathrm{OM}}$ & 10.46 & 10.62 & 1.11 & 0.89 \\
\hline $\mathrm{K}_{\mathrm{NDF}}$ & 5.09 & 6.55 & 0.63 & 0.12 \\
\hline $\mathrm{K}_{\text {starch }}$ & 54.72 & 58.21 & 9.42 & 0.73 \\
\hline $\mathrm{K}_{\mathrm{p}}^{2}$ & 3.53 & 2.98 & 0.42 & 0.24 \\
\hline
\end{tabular}

${ }^{1} \mathrm{LCW}=$ Low cell wall content and digestibility corn silage, $\mathrm{HCWN}=$ high cell wall content and digestibility corn silage substituted on a NDF basis.

${ }^{2}$ Passage rate as measured by indigestible NDF of TMR and ruminal digesta.
Table 10. Ruminal $\mathrm{pH}$ and VFA concentrations as influenced by diet (trial 2).

\begin{tabular}{|c|c|c|c|c|}
\hline \multirow[b]{2}{*}{ Item } & \multicolumn{2}{|c|}{$\operatorname{Diets}^{1}$} & \multirow[b]{2}{*}{ SEM } & \multirow[b]{2}{*}{$P$} \\
\hline & LCW & HCWN & & \\
\hline Rumen $\mathrm{pH}^{2}$ & 5.78 & 5.73 & 0.03 & 0.12 \\
\hline \multicolumn{5}{|l|}{ VFA, $\mathrm{m} M$} \\
\hline Acetate & 83.4 & 81.5 & 1.8 & 0.35 \\
\hline Propionate & 28.6 & 26.8 & 1.0 & 0.11 \\
\hline Isobutyrate & 1.4 & 1.5 & 0.1 & 0.34 \\
\hline n-butyrate & 17.1 & 18.4 & 0.9 & 0.20 \\
\hline Isovalerate & 2.2 & 2.3 & 0.1 & 0.39 \\
\hline n-valerate & 2.2 & 2.5 & 0.2 & 0.30 \\
\hline Total VFA, $\mathrm{m} M$ & 135.0 & 132.8 & 3.4 & 0.54 \\
\hline Acetate:propionate & 2.9 & 3.1 & 0.1 & 0.07 \\
\hline
\end{tabular}

${ }^{1} \mathrm{LCW}=$ Low cell wall content and digestibility, $\mathrm{HCWN}=$ high cell wall content and digestibility substituted on a NDF basis.

${ }^{2} \mathrm{Mean} \mathrm{pH}$ and VFA from samples collected every $4 \mathrm{~h}$ for $24 \mathrm{~h}$.

HCWN diet compared with the LCW diet increased (46.9 and $36.5 \%$, respectively). Total-tract starch digestibility averaged $81.6 \%$ for both treatments, which is on the lower end of the reported range (85 to 99\%; Firkins et al., 2001) Starch digestibility is a function of genetics, grain processing, and the assay used for measuring starch. There was no difference between diets for measures of ruminal mass or volume, although numerically these measures were all smaller for cows fed the HCWN diet (Table 9). The numerically lower ruminal volumes, along with the higher ruminal turnover values, may help to explain the trend for increased DMI observed for cows fed the HCWN diet. In this trial, the increased total tract digestibility of NDF allowed for the slight increase in DMI, which appears to be the driving factor for the increase in $4 \% \mathrm{FCM}$ production.

Ruminal $\mathrm{pH}$ and VFA concentration. There was a trend $(P=0.12)$ for lower ruminal $\mathrm{pH}$ for cows fed the HCWN diet compared with the LCW $\operatorname{diet}$ (5.73 and 5.78 for HCWN and LCW diet, respectively; Table 10) although the small difference between the 2 diets is not biologically important. There was no effect of diet on individual VFA concentrations or total VFA concentration. There was an increase in the acetate to propionate ratio for cows fed the HCWN diet compared with the LCW diet (3.1 and 2.9 for HCWN and LCW, respectively; $P<0.07)$. The higher acetate to propionate ratio is consistent with the higher milk-fat concentration observed for cows fed the HCWN diet.

Relationship of milk response to pretrial milk yield. There was a significant linear relationship between the milk yield response to the HCWN diet vs. the LCW diet and PM (Figure 2). In general, a 1 percentage unit increase in PM lead to a $0.15-\mathrm{kg}$ increase in response to the diet containing the higher NDF, higher NDF digestibility silage. 
A

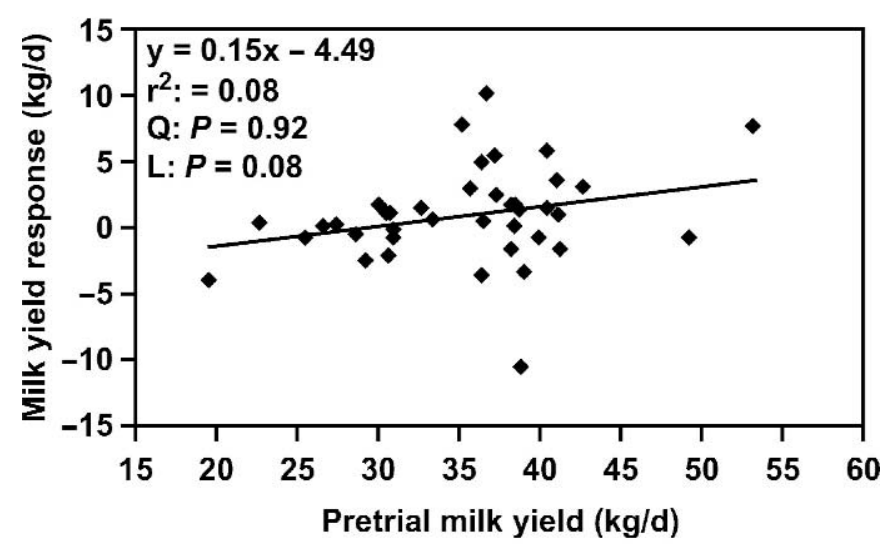

B

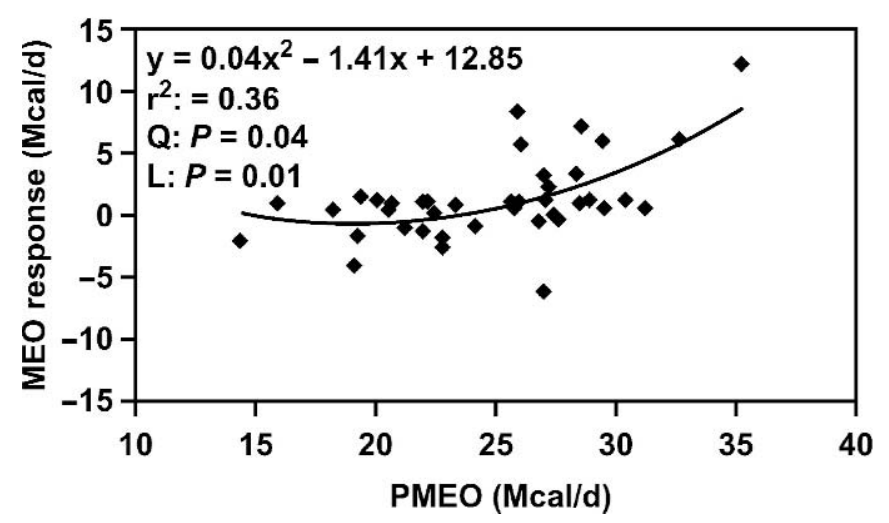

Figure 2. Relationship between pretrial milk yield or milk energy output, measured during last week of 2-wk preliminary period, and response to HCWN (high cell-wall content and digestibility substituted on a NDF basis) diet over the LCW (low cell-wall content and digestibility) diet in: $\mathrm{A}$ ) milk yield ( $\mathrm{SE}$ for slope $=0.62$ and intercept $=$ 11.16), or B) milk net energy output ( $\mathrm{SE}$ for $\mathrm{x}^{2}=0.02, \mathrm{x}=0.86$, and intercept $=10.59$ ). Milk net energy output was calculated as follows: $\mathrm{NE}_{\mathrm{L}(\text { milk })}(\mathrm{Mcal} / \mathrm{d})=\mathrm{MY}(\mathrm{kg}) \times[0.0929 \times($ Fat \% $)+0.0563 \times($ True Protein \% $+0.0395 \times($ Lactose \%) $(\mathrm{NRC}, 2001)$. PMEO $=$ Pretrial milk net energy output, $\mathbf{M E O}=$ milk net energy output, $\mathrm{Q}=$ quadratic, $\mathrm{L}=$ linear.

The response to the HCWN diet in relation to PMEO was quadratic. The $\mathrm{r}^{2}$ value for this curve was stronger compared with the milk energy output curve in trial 1 (0.36 for trial 2 compared with 0.12 for trial 1 ). For the HCWN diet vs. the LCW diet there was a significant positive correlation between the response and PMEO $(\mathrm{r}=0.53, P<0.01)$. This clearly shows that cows with higher PMEO were able to respond to a greater extent compared with cows with lower pretrial milk output. This result is in agreement with the findings of Oba and Allen (1998), who showed that milk yield response to a brown midrib silage-containing diet was greater for animals that were at a higher level of milk production before the start of the trial. Their hypothesis that the increased digestibility of the brown midrib silage led to increased ruminal turnover and therefore increased feed intake and milk production also applies to the results found in our study. Voelker et al. (2002) observed the same response, with higher producing cows having a greater $3.5 \% \mathrm{FCM}$ response to a lower forage diet than lower producing cows. Other factors such as DIM, parity, and BW could influence PM and therefore the response to the treatment. There was a negative correlation between pretrial DIM and PM $\left(\mathrm{r}^{2}=(0.39)\right.$, which reflects our use of late-lactation animals to create the lower end of our range in pretrial milk production.

\section{CONCLUSIONS}

Substituting corn silage with higher NDF content and digestibility for a silage with lower NDF content and digestibility, on either a DM or NDF basis, resulted in increased feed intake (\% of BW) and 4\% FCM production for those cows, but the response was lower when substitution occurred on an NDF basis. When the HCW silage was substituted for LCW silage on a DM basis, the increased turnover of $\mathrm{OM}$ and $\mathrm{NDF}$ accounted for the observed increase in feed intake and milk production. In contrast, when the HCW silage was substituted for LCW silage, on a NDF basis, the increase in totaltract digestibility appeared to contribute to the increase in milk yield to a greater extent than NDF turnover. Higher milk-producing cows responded greater to substitution of HCW for LCW silage when the substitution occurred on a NDF basis.

\section{REFERENCES}

Allen, M. S., K. A. O’Neil, D. G. Main, and J. F. Beck. 1991. Relationships among yield and quality traits of corn hybrids for silage. J. Dairy Sci. 74(Suppl. 1):221.

Association of Official Analytical Chemists. 1990. Official Methods of Analysis. 13th ed. AOAC, Washington, DC.

Bal, M. A., R. D. Shaver, J. Al-Jobeile, J. G. Coors, and J. G. Lauer. 2000. Corn silage hybrid effects on intake, digestion, and milk production by dairy cows. J. Dairy Sci. 83:2849-2858.

Ballard, C. S., E. D. Thomas, D. S. Tsang, P. Mandebvu, C. J. Sniffen, M. I. Endres, and M. P. Carter. 2001. Effect of corn silage hybrid on dry matter yield, nutrient composition, in vitro digestion, intake by dairy heifers, and milk production by dairy cows. J. Dairy Sci. 84:442-452.

Cochran, R. C., and M. L. Galyean. 1994. Measurement of in vivo forage digestion by ruminants. Pages 613-643 in Forage Quality, Evaluation, and Utilization. G. C. Fahey, Jr. ed. American Society of Agronomy, Inc., Crop Science Society of America, Inc., and Soil Science Society of America, Inc., Madison, WI.

Cox, W. J., J. H. Cherney, D. J. R. Cherney, and W. D. Pardee. 1994. Forage quality and harvest index of corn hybrids under different growing conditions. Agron. J. 86:277-282.

Dado, R. G., and M. S. Alllen. 1995. Intake limitations, feeding behavior, and rumen function of cows challenged with rumen fill from dietary fiber or inert bulk. J. Dairy Sci. 78:118-133.

Firkins, J. L., M. L. Eastridge, N. R. St-Pierre, and S. M. Noftsger. 2001. Effects of grain variability and processing on starch utilization by lactating dairy cattle. J. Anim. Sci. 79(Suppl. E):E218E238. 
Fleming, S. E., and R. D. Reichert. 1980. Note on a modified method for the quantitative determination of starch. Cereal Chem. 57:153-156.

Goering, H. K., and P. J. Van Soest. 1970. Forage Fiber Analyses (Apparatus, Reagents, Procedures, and Some Applications). Agric. Handbook. No 379. ARS-USDA, Washington, DC.

Hintz, R. W., D. R. Mertens, and K. A. Albrecht. 1996. Effects of sodium sulfite on recovery and composition of detergent fiber and lignin. J. AOAC 79:16-22.

Johnson, L., J. H. Harrison, C. Hunt, K. Shinners, C. G. Doggett, and D. Sapienza. 1999. Nutritive value of corn silage as affected by maturity and mechanical processing: A contemporary review. J. Dairy Sci. 82:2813-2825.

Kuehn, C. S., J. G. Linn, D. G. Johnson, H. G. Jung, and M. I. Endres. 1999. Effect of feeding silages from corn hybrids selected for leafiness or grain to lactating dairy cattle. J. Dairy Sci. 82:2746-2755.

Lammers, B. P., D. R. Buckmaster, and A. J. Heinrichs. 1996. A simple method for the analysis of particle sizes of forage and total mixed rations. J. Dairy Sci. 79:922-928.

National Research Council. 2001. Nutrient Requirements of Dairy Cattle. 7th rev. ed. Natl. Acad. Sci., Washington, DC.

Oba, M., and M. S. Allen. 1999a. Evaluation of the importance of the digestibility of neutral detergent fiber from forge: Effects on dry matter intake and milk yield of dairy cows. J. Dairy Sci. 82:589-596.

Oba, M., and M. S. Allen. 1999b. Effects of brown midrib 3 mutation in corn silage on dry matter intake and productivity of high yielding dairy cows. J. Dairy Sci. 82:135-142.

Oba, M., and M. S. Allen. 2000. Effects of brown midrib 3 mutation in corn silage on productivity of dairy cows fed two concentrations of dietary neutral detergent fiber: 3. Digestibility and microbial efficiency. J. Dairy Sci. 83:1350-1358.

Richards, C. J., J. F. Pedersen, R. A. Britton, R. A. Stock, and C. R. Krehbiel. 1995. In vitro starch disappearance procedure modifications. Anim. Feed Sci. Technol. 55:35-45.

SAS User's Guide: Statistics, Version 8.2 Edition. 2001. SAS Inst., Inc., Cary, NC.

Shaver, R. D., L. D. Satter, and N. A. Jorgensen. 1988. Impact of forage fiber content on digestion and digesta passage in lactating dairy cows. J. Dairy Sci. 71:1556-1565.

Valentin, S. F., J. M. Forbes, and P. Lescoat. 1999. Comparison of the voluntary intake by lactating cows of two maize silages with different in situ dry matter degradability. Ann. Zootech. 48:211-218.

Van Soest, P. J., J. B. Robertson, and B. A. Lewis. 1991. Methods for dietary fiber, neutral detergent fiber, and nonstarch polysaccharides in relation to animal nutrition. J. Dairy Sci. 74:35833597.

Voelker, J. A., G. M. Burato, and M. S. Allen. 2002. Effects of pretrial milk yield on response of feed intake, digestion, and production to dietary forage concentration. J. Dairy Sci. 85:2650-2661.

Weidner, S. J., and R. J. Grant. 1994. Soyhulls as a replacement for forage fiber in diets for lactating dairy cows. J. Dairy Sci. 77:513-521.

Weiss, W. P., and D. J. Wyatt. 2002. Effects of feeding diets based on silage from corn hybrids that differed in concentration and in vitro digestibility of neutral detergent fiber to dairy cows. J. Dairy Sci. 85:3462-3469.

Younker, R. S., S. D. Winland, J. L. Firkins, and B. L. Hull. 1998. Effects of replacing forage fiber or nonfiber carbohydrates with dried brewers grains. J. Dairy Sci. 81:2645-2656. 